\title{
Electric Vehicle and Infrastructure Codes and Standards Citations
}

This document lists codes and standards typically used for U.S. electric vehicle and infrastructure projects. To determine which codes and standards apply to a specific project, identify the codes and standards currently in effect within the jurisdiction where the project will be located. Some jurisdictions also have unique ordinances or regulations that could apply.

Learn about codes and standards basics at www.afdc.energy.gov/afde/codes_standards_basics.html.

Find electric vehicle and infrastructure codes and standards in these categories:

- Vehicle Systems

- Batteries

- Interface

- Infrastructure

\section{Vehicle Systems}

- SAE J-1634: Electric Vehicle Energy Consumption and Range Test

Status:

Cancelled: October 2002

Issued: October 2002

- SAE J-1711: Recommended Practice for Measuring the Exhaust Emissions and Fuel economy of Hybrid-Electric Vehicles

Status:

WIP official ballot in August 2009

Issued March 1999 (Original) and 69 pages in length

- SAE J-1715: Hybrid Electric Vehicle (HEV) and Electric Vehicle (EV) Terminology Status:

WIP in progress August 2009

Revised February 2008 and 22 pages in length

- SAE J-2344: Guidelines for Electric Vehicle Safety

Status:

WIP official ballot in August 2009 
Issued June 1998 (Original) and 11 pages in length

- SAE J-2464: Electric and Hybrid Electric Vehicle Rechargeable Energy Storage System (RESS) Safety and Abuse Testing

Status:

WIP in progress August 2009

Issued March 1999 (Original) and 15 pages in length

- SAE J-2711: Recommended Practice for Measuring Fuel Economy and Emissions of Hybrid-Electric and Conventional Heavy Duty Vehicles

Status:

Issued September 2002 and 68 pages in length

- SAE J-2758: Determination of the Maximum Available Power from a Rechargeable Energy Storage System on a Hybrid Electric Vehicle

Status:

Issued April 2007 and 7 pages in length

- SAE J-2889: Measurement of Minimum Sound Levels of Passenger Vehicles

Status:

WIP in Progress

Issued -No Originals

- SAE J-2894 Part 1: Power Quality Requirements for Plug-In Vehicle Chargers Requirements

Status:

WIP in Progress

Issued -No Originals

- SAE J-2894 Part 2: Power Quality Requirements for Plug-In Vehicle Chargers - Test Methods

Status:

WIP in Progress

Issued -No Originals 
- SAE J-2907: Power Rating Method for Automotive Electric Propulsion Motor and Power Electronics Sub-System

Status:

WIP in Progress

Issued -No Originals

- SAE J-2908: Power Rating Method for Hybrid-Electric and Battery Electric Vehicle Propulsion

Status:

WIP in Progress

Issued-No Originals

- ISO/FDIS 6469-1:2009(E): "Electrically propelled road vehicles - Safety specification Part 1: On-board rechargeable energy storage system (RESS)"

Status:

WIP in Progress

Issued -No Originals

- ISO/FDIS 6469-2:2009(E): "Electrically propelled road vehicles - Safety specification Part 2: Vehicle Operational Safety Means and Protection against Failures"

Status:

WIP in Progress

Issued -No Originals

- ISO/CD 6469-3.3: "Electrically propelled road vehicles - Safety specification - Part 3:

Protection of persons against electric shock"

Status:

WIP in Progress

Issued -No Originals

- ISO/WD 23274-2: "Hybrid-electric road vehicles - Exhaust emissions and fuel consumption measurements - Part 2: Externally chargeable vehicles"

Status:

WIP in Progress

Issued -No Originals 
- ISO XXX "Terminology Technical Report"

Status:

WIP in Progress

Issued -No Originals

\section{Batteries}

- SAE J-1766: Recommended Practice for Electric and Hybrid Electric Vehicle Battery Systems Crash Integrity Testing

Status:

Revised: April 2005 and 16 pages in length

Issued: February 1996

- SAE J-1797: Recommended Practice for Packaging of Electric Vehicle Battery Modules Status:

Reaffirmed June 2008 and 23 pages in length

Issued January 1997 (Original)

- SAE J-1798: Recommended Practice for Performance Rating of Electric Vehicle Battery Modules

Status:

Reaffirmed July 2008 and 16 pages in length

Issued January 1997 (Original)

- SAE J-2288: Life Cycle Testing of Electric Vehicle Battery Modules

Status:

Reaffirmed June 2008 and 5 pages in length

Issued January 1997 (Original)

- SAE J-2289: Electric-Drive Battery Pack System: Functional Guidelines

Status:

Revised July 2008 and 14 pages in length

Issued November 2000 (Original)

- SAE J-2380: Vibration Testing of Electric Vehicle Batteries 
Status:

Revised March 2009 and 7 pages in length

Issued January 1998 (Original)

- ISO/CD 12405-1: "Electrically propelled road vehicles - Test specification for lithiumion traction battery packs and systems - Part 1 "High power applications"

Status:

WIP in Progress

Issued -No Originals

\section{Interface}

- SAE J-1772: SAE Electric Vehicle Conductive Charge Coupler

Status:

WIP August 2009 (To be balloted in September if passed should be published in early fall 2009)

Revised November 2001 and 32 pages in length

Issued October 1996 (Original)

- SAE J-1773: SAE Electric Vehicle Inductively-Coupled Charging

Status:

Reaffirmed May 2009 and 35 pages in length

Reissued November 1999

Issued January 1995

- SAE J-1850: Class B Data Communications Network Interface

Status:

Reaffirmed June 2006 and 46 pages in length

Reaffirmed May 2001

Issued November 1988 (Original)

- SAE J-2293 Part 2: Energy Transfer System for EV Part 2: Communications Requirements and Network Architecture

Status:

Reaffirmed July 2008 and 196 pages in length 
Issued May 1997 (Original)

- SAE J-2836 Part 1: Use Cases for Communications between Plug-In Vehicles and the Utility Grid

Status:

WIP in Progress April 2009

Issued -No Originals

- SAE J-2836 Part 2: Use Cases for Communications between Plug-In Vehicles and the Supply Equipment (EVSE)

Status:

WIP in Progress February 2009

Issued -No Originals

- SAE J-2836 part 3: Use Cases for Communications between Plug-In Vehicles and the Utility grid for Reverse Flow

Status:

WIP in Progress February 2009

Issued -No Originals

- SAE J-2847 Part 1: Communications between Plug-In Vehicles and the Utility Grid Status:

WIP in Progress April 2009

Issued -No Originals

- SAE J-2847 Part 2: Communication between Plug-in Vehicles and the Supply Equipment (EVSE)

Status:

WIP in Progress

Issued -No Originals

- SAE J-2847 Part 3: Communication between Plug-in Vehicles and the Utility Grid for Reverse Power Flow

Status:

WIP in Progress

Issued -No Originals 


\section{Infrastructure}

- SAE J-2293 Part 1: Energy Transfer System for EV Part 1: Functional Requirements and System Architecture

Status:

Reaffirmed July 2008 and 84 pages in length

Issued March 1997 (Original)

- SAE J-2841: Utility Factor Definitions for Plug-In Hybrid Electric Vehicles Using 2001

U.S. DOT National Household Travel Survey Data

Status:

WIP in Progress

Issued March 2009 and 15 pages in length

- National Fire Protection Agency (NFPA) NFPA 70 National Electrical Code (NEC) Article 625: Electric Vehicle Charging System Equipment

Status:

WIP for NEC January 2011

Issued -NEC January 1996 and 4 pages in length

- National Fire Protection Agency (NFPA) NFPA 70 National Electrical Code (NEC) Article 626: Electrified Truck Parking Spaces

Status:

WIP for NEC January 2011

Issued -NEC January 2008 and 5 pages in length 